$\underline{\text { Performance and Behavior of Family Firms }}$

By: Esra Memili

Memili, E. Performance and Behavior of Family Firms. (2015). International Journal of Financial Studies, Special Issue on Family Firms.

Made available courtesy of Multidisciplinary Digital Publishing Institute (MDPI): http://dx.doi.org/10.3390/ijfs3030423

***(C) Multidisciplinary Digital Publishing Institute (MDPI). Reprinted with permission. No further reproduction is authorized without written permission from Multidisciplinary Digital Publishing Institute (MDPI). This version of the document is not the version of record. Figures and/or pictures may be missing from this format of the document. ***

(c) $(1) \odot$

EY NO NO This work is licensed under a Creative Commons AttributionNonCommercial-NoDerivatives 4.0 International License.

\begin{abstract}
:
This Guest Editor's note reflects on the contributions of each article in the Special Issue on family firms' behavior and performance. Building on this, several under-researched areas concerning family involvement in businesses are identified and the resulting impact on firm behavior and performance is explained. Finally, future research directions and insights for practitioners are outlined.
\end{abstract}

Keywords: family firm | family involvement | firm performance | firm behavior

Article:

***Note: Full text of article below 


\title{
Editorial
}

\section{Performance and Behavior of Family Firms}

\section{Esra Memili}

Bryan School of Business and Economics, University of North Carolina at Greensboro, 370 Bryan, Greensboro, NC 27402, USA; E-Mail: e_memili@uncg.edu; Tel.: +1-662-617-1459

Academic Editor: Nicholas Apergis

Received: 21 July 2015 / Accepted: 1 September 2015 / Published: 9 September 2015

\begin{abstract}
This Guest Editor's note reflects on the contributions of each article in the Special Issue on family firms' behavior and performance. Building on this, several under-researched areas concerning family involvement in businesses are identified and the resulting impact on firm behavior and performance is explained. Finally, future research directions and insights for practitioners are outlined.
\end{abstract}

Keywords: family firm; family involvement; firm performance; firm behavior

\section{Introduction}

I am pleased to announce the first Special Issue on Family Firms in the International Journal of Financial Studies. The focus of articles in this Special Issue is mostly on family enterprises' behavior and performance. In addition, one article provides a review of the definition of family firms in the literature. This Guest Editor's note synthesizes the contributing authors' propositions and findings regarding family firms in different parts of the world and suggests future research directions.

Indeed, a large number of firms around the world exhibit family involvement in various ways (e.g., family ownership), which can significantly impact their strategies, behavior, and performance. When family business members have intentions to pursue particularistic goals and strategies, they are more likely to be influential on firm strategies, behavior, and performance. Such intentions can lead to strategic behaviors that are often oriented toward preserving the economic and socioemotional wealth of the firm for the family in the long run. Consequently, family firm behavior is expected to be distinct from those in non-family firms and among family firms. Since family firms are key value creators around the globe (Bertrand and Schoar [1]), we invited researchers to shed light on how families use their influence to affect the behavior and performance of firms. Taking a closer look at the effects of 
family involvement on these companies across the world helps us also appreciate the research progress made to date and identify the areas deserving future research. This Guest Editor's note provides such a discussion, distilling key findings and how they could enrich future theory building and testing.

This Special Issue on Family Firms and the Guest Editor's Note can guide future research in several ways. First, the importance of family governance to explain how families control corporations differently is highlighted. By doing so, this Special Issue draws attention to the differences between publicly traded family and non-family firms that are likely to have an impact on firm behavior performance. Second, this Special Issue helps us better understand how family involvement in the business can influence firm behavior and performance. This improves our understanding of the heterogeneity among family firms. Third, new insights and future research directions regarding behavior and performance differences between family and non-family firms as well as among family firms themselves are provided.

The remainder of the Guest Editor's Note will progress as follows: First, this Editor's Note will summarize each article in the Special Issue. Then, key propositions and findings and their theoretical and practical implications are evaluated. This allows identification of several under-researched areas that require close scholarly attention. In the final section of the Guest Editor's note, promising future research directions and insights for practitioners are discussed.

\section{Articles}

\subsection{Definition of Family Business}

Since the findings on behavior and performance in previous studies might be affected by the family firm definition, the review of Harms [2] is particularly important in this Special Issue. Harms [2] identifies six different clusters by focusing on the most frequently used definitions in previous research.

Components of Involvement and Essence Approaches have been grouped together since this categorization by Chua, Chrisman and Sharma [3] suggests that components factors, such as ownership or control, have to be combined with elements depicting the essence of family businesses, such as visions and intentions. Studies based on Chua et al. [3] and more recent updates (e.g., Chrisman et al. [4]) systematically differentiate between family and non-family firms as well as among family businesses themselves, suggesting that components and essence factors are jointly crucial to account for family firms' uniqueness.

Definitions with Empirical Focus are explicitly geared toward conducting empirical analyses. First introduced by Anderson and Reeb [5] and extended by Villalonga and Amit [6], this definitional approach specifies operational criteria to empirically measure family business characteristics, especially those with effects on the relationship between family ownership and firm performance. Definitions applied before the publication of the aforementioned definitional concepts as well as those intended to account to specific research designs are summarized under Other Definitions. Self-Developed Definitions categorize studies in which the authors neglected previous definitions and based their studies on new sub-classification and self-developed approaches. In contrast to those assigned to the other clusters, studies Without Explicit Definition did not refer to any family firm definition or solely pointed to the used data source without defining the object of investigation. 
Furthermore, Harms [2] assigned some studies to the cluster F-PEC or "Familiness" (i.e., family influence by power, experience, and culture) (Astrachan et al. [7]), which contains all studies targeted at discussing "soft factors", such as family's values or commitment to the business. These definitions partly build on the components of involvement or essence approach, but highlight the importance of experience and culture to explain family firms' distinctiveness.

\subsection{Financial Performance in Family versus Non-Family Publicly Traded Firms}

A prominent stream of research shows that family firms may outperform non-family firms around the world (e.g., Anderson and Reeb [5]; Andres [8]). While investigating the performance differences between not only family and non-family firms, but also among family firms, studies also draw attention to different family involvement configurations (e.g., founding family control vs. descendant family control, family vs. non-family CEO, the degree of board independence, and family firm types), which may lead to performance differences not only between family and non-family firms, but also among family firms as well (Anderson and Reeb [5,9]; Villalonga and Amit [6]). Research to date shows that these different configurations of family ownership and management can be associated with firm value positively or negatively or exhibit no relationship (O’Boyle et al. [10]; Peng and Jiang [11]). Hence, findings are mixed concerning the performance differences between founder-controlled and descendant-controlled family firms.

On the one hand, research shows that founder-controlled firms can outperform not only non-family firms, but also descendant-controlled family firms (Andres [8]; Miller and Le Breton-Miller [12]; Villalonga and Amit [6]). According to Miller and Le Breton-Miller [12], the success factors in founder-controlled firms are family owners' voting rights deriving from significant equity rights, a strong CEO without complete voting control and accountable to independent directors, multiple family members serving as managers, and transgenerational succession intentions. Morck et al. [13] show that heir-controlled Canadian firms exhibit low financial performance, which can be a factor that impedes economic growth. This may stem from the entrenchment of unqualified family managers (Morck et al. [13]). The descendants may also pursue the private benefits of control when they are wealthy enough to do so through inherited wealth. Another reason may be that the positive effects of family influence tend to be weaker in later generations when family influence is more dispersed or fractionalized (Gomez-Mejia et al. [14]).

Some scholars, however, argue the opposite by showing that descendant-controlled firms are more efficient and profitable than founder-controlled firms even though founder-controlled firms tend to grow faster and invest more in capital assets and research and development (McConaughy et al. [15]; McConaughy et al. [16]). Similarly, Morck et al. [13] show that firm performance becomes lower when the firm is run by a member of the founding family than when it is run by an officer unrelated to the founder in older firms. According to Sraer and Thesmar [17], family firms largely outperform non-family firms regardless of being controlled by the founding or descendant families in control in France. However, Miller et al. [18] show that only businesses with a lone founder, rather than a founding family, outperform others among Fortune 1000 firms. Miller and Le Breton-Miller [12] observe that family-controlled businesses perform well when they mitigate agency costs and foster stewardship behaviors among leaders. 
In this Special Issue, five articles take a closer look at the impact of family involvement on firm performance within different contexts in different countries (i.e., US, Poland, Mexico, and China), giving us the comparison opportunity across different parts of the world.

First, Noguera and Chang [19] examine Real Estate Investment Trust (REIT) founders versus successors through the lens of the socioemotional wealth (SEW) perspective. The authors show that founders preserve SEW by appointing a descendant as the REIT CEO and using the family name to identify the REIT. On the one side, REITs led by successors underperform other REITS (led by professional managers after succeeding the REIT founder or REITs led by their founders) and independent board members are not positively influential in REITs' governance. On the other side, the family identification through the use of family name in REIT influences performance positively.

The paper by Lipiec [20] examines how publicly-traded family firms perform during economic downturns compared to non-family firms in the construction sector in Poland. The author shows that publicly-traded family firms significantly outperform non-family peers during economic crisis and presents future research directions in regards to the determinants of performance in these outperforming family firms.

The article by San Martin-Reyna and Duran-Encalada [21] shows a positive link between family ownership concentration and performance among publicly-traded firms in Mexico. In addition, lower levels of debt and less participation by independent directors in family businesses strengthens this positive link. Nevertheless, in non-family firms, higher levels of participation by independent directors and debt contribute to better performance.

Relevant to San Martin-Reyna and Duran-Encalada's [21] work, the article by Luo and Liu [22] in this Special Issue, examines publicly-traded family firms in China. The authors show that there is an inverted U-shaped relationship between family ownership concentration and corporate value, and board independence positively moderates this relationship, suggesting interest-alignment effects of family ownership concentration up to an optimum level. After an optimum level, entrenchment effects prevail.

Consistent with Luo and Liu's [22] work, Memili and Misra [23] examine the S\&P 500 firms and show the moderation effects of corporate governance provisions on the inverted U-shaped links between family involvement (i.e., family ownership and family management) in publicly-traded firms and firm performance by drawing upon agency theory, with a focus on principal-principal agency issues, and the extant family governance literature. Hence, both family involvement and the use of governance provisions are influential on firm performance in publicly-traded firms in the US.

\subsection{Family Firm Behavior}

Aside from the performance outcomes of family involvement, the Special Issue presents two articles on Family Firm Behavior in the forms of Corporate Social Responsibility (CSR) and Succession.

\subsubsection{CSR in Family Firms}

CSR studies focusing on family firms suggest that family business owners' greater commitment to the family firm, direct contact with customers, proactiveness in nurturing relationships with all stakeholders, long-term orientation, involvement in the community, and reputation concerns can 
facilitate CSR activities (Bingham et al. [24]; Deniz and Suárez [25]; Dyer and Whetten [26]; Uhlaner et al. [27]).

In this Special Issue, Hirigoyen and Poulain-Rehm [28] demonstrate that publicly-traded family businesses in Europe, Asia, and North America do not differ from non-family firms in CSR activities in the forms of human resources (i.e., industrial relations, employment relations, and working conditions), human rights (i.e., freedom of association, promotion of collective bargaining, non-discrimination, equality, elimination of child or any forced labor as well as harassment, and protection of personal data), community involvement, protection of environment, and business relations (i.e., rights and interests of customers, integration of social and environmental standards in the selection of suppliers, and respect for competition rules). The authors also show a negative relationship between family governance and corporate governance practices in terms of the balance of power and effectiveness of board, audit and control mechanisms, engagement with shareholders, and executive compensations.

\subsubsection{Succession in Family Firms}

Intra-family succession is critical for family firms' longevity. Boyd and colleagues [29] develop a conceptual model of incumbent decisions on succession in family firms by drawing upon the theory of planned behavior and socioemotional wealth (SEW). The authors suggest that family, firm, industry, and cultural contexts can shape concerns about family and business, in turn affecting attitudes toward the type of succession, norms, and perceived behavioral control. These can consequently determine the intention toward a particular type of succession.

\section{Discussion and Conclusions}

There has been a prominent stream of research investigating whether family firms outperform non-family firms. The general conclusion has been that they do. However, performance differences also depend upon the type of family involvement (e.g., founder control) (e.g., Anderson and Reeb [5]; Miller et al. [18]; Villalonga and Amit [6]). There has been also an increase in research examining family firm performance and its antecedents, owing to the critical role of firm value in buy-out decisions, tax payments, executive compensation, capital raising strategies, and selling the company (Villalonga [30]). The articles in this Special Issue (e.g., Lipiec [20]; San Martin-Reyna and Duran-Encalada [21]) are in line with studies showing that family ownership and management can enhance firm value since the controlling family can provide superior oversight through lengthy tenure, investment in long-term projects, or exhibit reputation concerns that diminish the possibility of questionable or irresponsible business practices (Anderson and Reeb [5]; Dyer and Whetten [26]). Nevertheless, family involvement can also result in negative firm behavior and performance, if principal-principal agency problems prevail, particularly after an optimum level of family ownership and/or management (e.g., Luo and Liu [22]; Memili and Misra [23]).

Existing research generally explores the use of various governance mechanisms and performance differences between family firms and non-family firms and among family firms by drawing upon agency theory with a focus on principal-principal agency issues (e.g., Memili [31]; Memili and Misra [23]). However, institutional factors tend to play a role in governance systems as well. Accordingly, a recent 
review by Gedajlovic et al. [32] suggests that the effects of family firm governance may depend on the existence of institutional factors. Indeed, family owners and managers may have more or less power than their peers in different countries (Memili [31]). For example, in the US, family owners and managers may not have as high levels of discretion power as peers in some other countries owing to effective investor protection. Accordingly, Peng and Jiang [11] suggest that the impact of family ownership and control on firm value is associated with the level of shareholder protection ensured by legal and regulatory institutions of a country. On the one hand, when there is effective investor protection, family owners tend to dilute their equity to attract minority shareholders and delegate management to professional managers (Peng and Jiang [11]). In this case, family owners and managers do not have the need or motivation to use control enhancing governance mechanisms to enhance their power. On the other hand, when the legal system is weak, ownership becomes more concentrated by family owners who would seek to ensure their control by participating in management (Peng and Jiang [11]). However, the negative aspect of the enhanced power of the controlling family in an environment characterized by weak legal investor protection is the likelihood of principal-principal agency problems such as expropriation of non-controlling shareholder wealth and entrenchment of the controlling family. Therefore, future research would benefit from exploring the relative effects of institutionalization versus family influence on firm performance through the lens of institutional theory within the context of different countries' legal regimes.

The meta-analytic approaches for examining the link between family involvement in corporations and firm performance will be particularly helpful to reconcile the inconsistencies in prior findings through a quantitative integration of the results of previous studies. This can allow for calculating an overall effect through consolidating available empirical evidence into a single quantitative effect size, and testing the role of various contingency factors, such as sample differences, study design differences, measures, regions, and more. The meta-analytic review (e.g., O'Boyle et al. [10]; Wagner et al. [33]) can thereby help integrate available empirical evidence, while at the same time identifying under-researched areas. More specifically, this type of review can highlight the importance of different forms of family involvement in publicly-traded firms to explain how families control corporations differently. By doing so, it can contribute to a better understanding of the differences between publicly-traded family and non-family firms that are likely to have an impact on firm performance. Second, it can add to the literature by reviewing different publicly-traded family firm governance contexts and contingencies that can influence firm performance. By this, our understanding of the heterogeneity among family firms (Melin and Norqvist [34]) will be improved. Third, new insights and future research directions regarding corporate governance differences between family and non-family firms as well as among family firms can be provided.

This Guest Editor's Note summarizes the articles in the Special Issue, explains the relevance as well as differences among the articles, and draws attention to different contexts (e.g., the extent of institutionalization and the legal environment) that may play a role in family firm behavior and performance. If publicly traded family firms can capitalize on the positive effects of family involvement and mitigate agency problems, they can achieve superior performance. Publicly traded family firms concerned with maximizing shareholder value and attaining competitive advantages through family control will be sought after by investors and reap the benefits of positive corporate image. 


\section{Conflicts of Interest}

The author declares no conflict of interest.

\section{References}

1. Bertrand, M.; Schoar, A. The role of family in family firms. J. Econ. Perspect. 2006, 20, 73-96.

2. Harms, H. Review of Family Business Definitions: Cluster Approach and Implications of Heterogeneous Application for Family Business Research. Int. J. Financ. Stud. 2014, 2, 280-314.

3. Chua, J.H.; Chrisman, J.J.; Sharma, P. Defining the family business by behavior. Entrep. Theory Pract. 1999, 23, 19-39.

4. Chrisman, J.J.; Chua, J.H.; Sharma, P. Trends and directions in the development of a strategic management theory of the family firm. Entrep. Theory Pract. 2005, 29, 555-576.

5. Anderson, R.C.; Reeb, D.M. Founding-family ownership and firm performance: Evidence from the S\&P 500. J. Financ. 2003, 58, 1301-1328.

6. Villalonga, B.; Amit, R. How do family ownership, management, and control affect firm value? J. Financ. Econ. 2006, 80, 385-417.

7. Astrachan, J.H.; Klein, S.B.; Smyrnios, K.X. The F-PEC scale of family influence: A proposal for solving the family business definition problem. Fam. Bus. Rev. 2002, 15, 45-58.

8. Andres, C. Large shareholders ad firm performance: An empirical examination of founding-family ownership. J. Corp. Financ. 2008, 14, 431-445.

9. Anderson, R.C.; Reeb, D.M. Who Monitors the Family? Available online: http://papers.ssrn.com/ sol3/papers.cfm?abstract_id=369620 (accessed on 21 July 2015).

10. O'Boyle, E.H.; Pollack, J.M.; Rutherford, M.W. Exploring the relation between family involvement and firms' financial performance: A meta-analysis of main and moderator effects. J. Bus. Ventur. 2012, 27, 1-18.

11. Peng, M.W.; Jiang, Y. Institutions behind family ownership and control in large firms. J. Manag. Stud. 2010, 47, 253-273.

12. Miller, D.; le Breton-Miller, I. Family governance and firm performance: Agency, stewardship, and capabilities. Fam. Bus. Rev. 2006, 19, 73-88.

13. Morck, R.; Strangeland, D.A.; Yeung, B. Inherited Wealth, Corporate Control and Economic Growth: The Canadian Disease? Working Paper 6814; National Bureau of Economic Research: Cambridge, MA, USA, 1998.

14. Gómez-Mejía, L.R.; Hynes, K.T.; Núñez-Nickel, M.; Moyano-Fuentes, H. Socioemotional wealth and business risk in family-controlled firms: Evidence from Spanish olive oil mills. Adm. Sci. $Q$. 2007, 52, 106-137.

15. McConaughy, D.L.; Phillips, G.M. Founders versus descendants: The profitability, efficiency, growth characteristics, and financing in large, public, founding-family-controlled firms. Fam. Bus. Rev. 1999, 12, 123-132.

16. McConaughy, D.L.; Walker, M.C.; Henderson, G.V.; Mishra, C.S. Founding family controlled firms: Efficiency and value. Rev. Financ. Econ. 1998, 7, 1-19. 
17. Sraer, D.; Thesmar, D. Performance and behavior of family firms: Evidence from the French stock market. J. Eur. Econ. Assoc. 2007, 5, 709-751.

18. Miller, D.; le Breton-Miller, I.; Lester, R.H.; Cannella, A.A. Are family firms really superior performers? J. Corp. Financ. 2007, 13, 829-858.

19. Noguera, M.; Chang, E.P.C. Socio Emotional Wealth Preservation in the REIT Industry: An Exploratory Study. Int. J. Financ. Stud. 2014, 2, 220-239.

20. Lipiec, J. Capital Asset Pricing Model Testing at Warsaw Stock Exchange: Are Family Businesses the Remedy for Economic Recessions? Int. J. Financ. Stud. 2014, 2, 266-279.

21. San Martin-Reyna, J.M.; Duran-Encalada, J.A. Effects of Family Ownership, Debt and Board Composition on Mexican Firms Performance. Int. J. Financ. Stud. 2015, 3, 56-74.

22. Luo, J.H.; Liu, H. Family-Concentrated Ownership in Chinese PLCs: Does Ownership Concentration Always Enhance Corporate Value? Int. J. Financ. Stud. 2014, 2, 103-121.

23. Memili, E.; Misra, K. Corporate Governance Provisions, Family Involvement, and Firm Performance in Publicly Traded Family Firms. Int. J. Financ. Stud. 2015, 3, 194-229.

24. Bingham, J.B.; Dyer, W., Jr.; Smith, I.; Adams, G.L. A Stakeholder Identity Orientation Approach to Corporate Social Performance in Family Firms. J. Bus. Ethics 2011, 99, 565-585.

25. De Ia Cruz Déniz Déniz, M.; Suárez, M. Corporate Social Responsibility and Family Business in Spain. J. Bus. Ethics 2005, 56, 27-41.

26. Dyer, W.G.; Whetten, D.A. Family firms and social responsibility: Preliminary evidence from the S\&P 500. Entrep. Theory Pract. 2006, 30, 785-802.

27. Uhlaner, L.M.; van Goor-Balk, H.J.M; Masurel, E. Family business and corporate social responsibility in a sample of Dutch firms. J. Small Bus. Enterp. Dev. 2004, 11, 186-194.

28. Hirigoyen, G.; Poulain-Rehm, T. The Corporate Social Responsibility of Family Businesses: An International Approach. Int. J. Financ. Stud. 2014, 2, 240-265.

29. Boyd, B.; Botero, I.C.; Fediuk, T.A. Incumbent Decisions about Succession Transitions in Family Firms: A Conceptual Model. Int. J. Financ. Stud. 2014, 2, 335-358.

30. Villalonga, B. Note on Valuing Control and Liquidity in Family and Closely Held Firms; Harvard Business School Publishing: Boston, MA, USA, 2009.

31. Memili, E. Control-Enhancing Corporate Governance Mechanisms: Family versus Non-family Publicly Traded Firms. Doctoral Dissertation, Mississippi State University, Mississippi State, MS, USA, 2011.

32. Gedajlovic, E.; Carney, M.; Chrisman, J.J.; Kellermanns, F.W. The adolescence of family firm research taking stock and planning for the future. J. Manag. 2012, 38, 1010-1037.

33. Wagner, D.; Block, J.H.; Miller, D.; Schwens, C.; Xi, G. A meta-analysis of the financial performance of family firms: Another attempt. J. Fam. Bus. Strategy 2015, 6, 3-13.

34. Melin, L.; Nordqvist, M. The reflexive dynamics of institutionalization: The case of the family business. Strateg. Organ. 2007, 5, 321-333.

(C) 2015 by the author; licensee MDPI, Basel, Switzerland. This article is an open access article distributed under the terms and conditions of the Creative Commons Attribution license (http://creativecommons.org/licenses/by/4.0/). 